\title{
Адаптивне управління в самоорганізації промислового підприємства
}

\author{
Світлана Бондаренко * 1 А; Олена Маковеєва 2 в \\ А Національний університет оборони України імені Івана Черняховського, пр-кт Повітрофлотський 28, м. Київ, 03049, Україна \\ в Одеський регіональний інститут державного управління Національної академії державного управління при Президентові України, вул. \\ Генуезська, 22, Одеса, 65009, Україна
}

Received: April 11, 2021 | Revised: April 28, 2021 | Accepted: April 30, 2021

JEL Classification: D01, D20

DOI: $10.33445 /$ sds.2021.11.2.21

\begin{abstract}
Анотація
В статті здійснюється дослідження адаптивного управління в контексті забезпечення належного рівня самоорганізації промислового підприємства. На основі показників звітності розроблено методику оцінки показника розвитку підприємства, що дозволяє визначити показник, який $€$ інтегральним коефіцієнтом самоорганізації. Пропонується модель для оцінки адаптивного потенціалу підприємства з використанням показника швидкості розвитку підприємства. При цьому, розрахована величина адаптивного потенціалу на основі показника самоорганізації, $є$ динамічним показником, який може виступати як критерій оцінки ефективного управлінської системи підприємства. Пропонується механізм адаптивного управління підприємством, в основу якого покладено формування адаптаційно-інноваційного середовища. Якостями адаптивного характеру для промислового підприємства, виділяються: наявність системи управління змінами; організація інноваційної діяльності; мотивація і розвиток персоналу, управління знаннями; формування інноваційної культури; управління інноваційними ризиками; організація фінансування інноваційної діяльності.
\end{abstract}

Ключові слова: адаптивне управління, адаптивний потенціал, самоорганізація, промислове підприємство.

\section{Постановка проблеми}

Завдання менеджменту на сучасному етапі полягає в тому, щоб знайти розумне збалансоване співвідношення кількісних і якісних змін конкретних показників розвитку підприємства з урахуванням фактору часу. Це означає, що розвиток підприємства має носити комплексний характер: з одного боку, стійке економічне зростання, а з іншого збалансованість бізнес-процесів та здатність адаптуватися до негативного впливу зовнішнього середовища.

Умовою формування середовища, здатного стимулювати інноваційний розвиток підприємств промисловості України $\epsilon$ впровадження концептуальної моделі бізнес-екосистеми інновацій, яка:

$$
\text { - грунтується на інтегрованому }
$$

багаторівневому управлінні, направленому на розповсюдження інноваційних компетенцій;

- спирається на ринкову ідеологію економіки, беручи за основу сучасні концепції менеджмент-маркетингу, ідеї створення кластерів, як новітніх форм об`єднання учасників для досягнення синергетичних ефектів розвитку;

- розглядає трансформацію ієрархічної системи управління В горизонтально-

\footnotetext{
1 * Corresponding author: д.е.н., професор кафедри оборонного менеджменту, e-mail: lana.bond@ukr.net, ORCID: 0000-0002-1687-1172

2 к.е.н., доцент, доцент кафедри менеджменту організацій, e-mail: makoveeva.e@ukr.net, ORCID: 0000-0003-2726-915X
} 
мережеву як практику послідовного усунення адміністративних бар'єрів для рівноправних взаємодій всіх соціальних груп;

- обгрунтовує створення платформи інноваційного розвитку 3 адекватним інфраструктурним забезпеченням (Бондаренко, 2017; 2018).

Особливої актуальності набуває розробка механізму адаптивного управління підприємством як відкритою соціальноекономічною системою (СЕС), здатною до самоорганізації, що дозволяє органічно поєднувати властивості стійкості і, одночасно, гнучкості і адаптивності. Основу такого механізму становить оцінка стадії розвитку підприємства, що визначає, у тому числі, i варіанти управлінського впливу на дану CEC. 3 огляду на це, оцінка розвитку підприємства - це багатокритеріальне завдання з великою кількістю показників, представлених у вигляді певних рядів динаміки. Аналітична оцінка розвитку підприємства стає основою для виділення цілей, напрямків і засобів його подальшого розвитку.

\section{Аналіз останніх досліджень та публікацій}

Основу методики динамічних нормативів заклав професор І.М.Сироєжин (1980), розробивши комплексний показник оцінки результатів господарювання економічних систем. У своїх дослідженнях щодо використання методу динамічних нормативів науковці наводять загальний алгоритм методу, приділяється увага методології застосування методу, є конкретні приклади його практичного використання, що стосується фінансового аналізу (Ефимова, 2002; Макаров, 2011; Михайлов, 2009; Погостинская, 2000; Тонких, 2012; Тищенко, 2005) та ін. Щодо оцінки розвитку підприємств 3 використанням методики динамічних нормативів, $\epsilon$ цікаві результати вітчизняних дослідників: (Гаркуша \& Смирнов, 2014). Однак, незважаючи на те, що методика динамічного нормативу $€$ досить відомою в економічній літературі, застосування іï при діагностиці розвитку підприємства (поточного рівня, потенціалу, цільових векторів) не набуло достатньо широкого висвітлення. В цьому сенсі особливий інтерес викликає робота Hellwig (1968), де представлена концепція показника рівня розвитку, згідно якої досліджувані об'єкти упорядковуються за відстанню до точки, яка $\epsilon$ еталоном розвитку. Hellwig одним із перших запропонував методику агрегування ознак у синтетичну величину, яка виражає вплив усіх ознак, що характеризують досліджуване економічне явище. Така синтетична величина, яка по суті $\epsilon$ таксономічним показником розвитку явища, використовується в багатовимірному аналізі в економічних дослідженнях (Кондратьев, 1989). “Розраховані таким чином значення показника розвитку описують динаміку змін досліджуваних ознак...., в узагальнюючій формі представляють зміни, що відбуваються в аналізованому явищі" (Плюта \& Иванова, 1989). Цей узагальнюючий показник (інтегральний коефіцієнт) можна представити як показник рівня розвитку, який акумулює в собі інформацію не лише про траєкторію розвитку підприємства (тобто, напрямок зміни основних показників діяльності), а й відображає пропорційність і сумарний ефект від їх зміни у часі. Вирішити завдання оцінки розвитку підприємства з позиції його цільової спрямованості, ресурсного забезпечення та стійкості можливо шляхом застосування математичного апарату багатовимірного статистичного аналізу, а саме таксономічного показника, що досить активно використовується у економічній практиці для комплексного аналізу статистичної сукупності об'єктів, охарактеризованих за допомогою певної системи критеріїв та ознак (Мажажихов \& Мисходжев, 2012).

\section{Постановка завдання}

Важливим аспектом менеджменту $€$ діагностика стадії розвитку підприємства, що 
надасть інформацію для розробки відповідних адаптивних заходів для підвищення ефективності управлінських рішень. На відміну від статичної характеристики, динамічний критерій $€$ набагато складнішим за своєю природою, оскільки $€$ основою визначення тенденції розвитку економічної системи, відображаючи в кожен момент часу той стан, до якого вона має прагнути.

Процедура знаходження інтегрального показника розвитку підприємства представлена на рисунку 1.

1. Відбір показників для оцінки розвитку підприємства, згідно цілям розвитку, розробка еталонної системи показників

2. Визначення темпів росту значень показників, розрахунок індексів темпів росту, їх ранжування, порівняння ранжованного ряду з еталонним

\begin{tabular}{c|} 
3. Розрахунок коесріцієнтів рангової кореляції \\
\hline 4. Визначення коефріцієнта самоорганізації і стадії розвитку підприємства \\
\hline 5. Визначення міри відхилення розвитку підприємства від цілей, ідентифрікація \\
«слабких місць» системи управління \\
\hline
\end{tabular}

6. Вибір «точок супротиву змінам» для управлінського впливу щодо адаптивних заходів

Рисунок 1 - Методика оцінки показника розвитку підприємства

Методика оцінки стадії розвитку підприємства розробляється з метою:

- моніторингу, спрямованого на оперативне виявлення критично важливих параметрів і визначення положення (стадії) підприємства в циклі саморозвитку;

- аналізу, призначеного для виявлення контрольних параметрів системи, здатної до самоорганізації, які потребують коригування;

- управління, тобто вироблення оптимальних управлінських впливів в залежності від виявлених в ході моніторингу та аналізу стадії розвитку і контрольних параметрів системи;

- прогнозування, заснованого на визначенні положення підприємства в циклі саморозвитку і передбачуваного переходу в наступну стадію.

Оцінка діяльності підприємства здійснюється не за рівнем того чи іншого показника, а за його збільшенням, що відображає динаміку об'єкта. На основі такої оцінки будується структурно-динамічна модель розвитку підприємства, яка має бути заснована на узгодженні темпів зростання різних, спеціально виділених показників. Вирішення даного завдання можливе за умови застосування принципів динамічної співпідпорядкованості і динамічної порівняності показників. Високий ступінь невизначеності, динамічність та нелінійність обумовлюють необхідність включення в модель показників, що характеризують взаємини підприємства із зовнішнім середовищем, а також індикатори, що відображають характер і стан внутрішньофірмових зв'язків і відносин. В моделі первинні (базові) і похідні показники дозволять установити співвідношення між ними і таким чином реалізувати вимоги взаємозв'язку. Наявність виділених базових показників дозволяє провести повну оцінку діяльності підприємства, тому що на їх основі можна визначити практично будь-які похідні показники в залежності від необхідних цілей. Похідні показники визначаються на основі базових, виходячи 3 галузевої специфіки промислового підприємства і його стратегічних 
цілей. Інструментом, який дозволяє аналізувати показники в динаміці, $є$ методика динамічних нормативів.

Темпові показники як індикатори швидкості розвитку аналізованих аспектів підприємства широко використовуються при виявленні тенденцій, закономірностей розвитку і діагностиці його проблем. При цьому аналізуються темпи зміни окремих часткових показників, так і темпові пропорції, а також темпова динаміка комплексних показників. В дослідженнях використовуються парні пропорції, системи парних пропорцій, ланцюжки пропорцій і комбіновані системи пропорцій, які об'єднують загальним поняттям - «динамічний норматив».

Методика динамічних нормативів заснована на формуванні фіксованого набору показників (динамічного нормативу), упорядкованих на основі ранжування їх руху (як правило, індексів темпів зростання). Важливою умовою застосування методу динамічних нормативів $\epsilon$ формування еталонної (нормативної) системи показників розвитку підприємства, процес розробки якої полягає у вирішенні двох завдань:

- по-перше, це побудова системи показників, оптимальної для оцінки діяльності підприємств конкретної галузі;

- по-друге, встановлення еталонного порядку зміни темпів зростання показників.

Фактичний порядок показників порівнюється 3 нормативним (еталонним) 3 використанням інструментів кореляційного аналізу.

Вибір критерію для класифікації показників, що включаються в систему оцінки функціонування і розвитку підприємства, пояснюється визначальним впливом когерентної взаємодії внутрішніх підсистем на діяльність підприємства. Критеріями є:

- динамічність показників та наявність зв'язків із середовищем, а також між підрозділами досліджуваного підприємства;

- відсутність дублювання (виняток складають показники, що розраховуються як відношення або добуток один на одного, оскільки даний метод оцінює показники через співвідношення темпів їх зростання);

- індивідуалізація профілю (виражається в різних одиницях виміру, виборі бази розрахунку, незначних змінах найменувань показників в залежності від галузевої специфіки і індивідуальних особливостей конкретного господарюючого суб'єкта);

- спрямованість на тактичну діяльність (регулювання стратегічних аспектів управління в даній системі показників здійснюється через моніторинг заданих еталонних співвідношень тактичних показників);

- чітка формалізація і кількісна оцінка;

- обмеження по числу (оптимальний набір показників включає 6-15 різноманітних індикаторів);

- можливість керуючого впливу (всі показники мають піддаватися коригуванню; кожен індикатор може бути контрольованим параметром, впливаючи на який, можливо «повернути» підприємство в стадію динамічної рівноваги);

- необхідність угрупування показників за обраною основою (функціональна спрямованість внутрішніх підсистем підприємства).

Система показників (еталон) для оцінки стадії розвитку підприємства представлено у таблиці 1.

Еталонна система показників відображає оптимальні умови функціонування і розвитку підприємства.

Встановлені співвідношення мають таку логічну інтерпретацію. Для успішно функціонуючого промислового підприємства характерним є випередження темпів зростання прибутку над зростанням виручки від реалізації продукції, який, в свою чергу, перевершує темп збільшення активів. Така закономірність указує на ефективну збутову політику підприємства.

Щодо співвідношення темпів зростання виручки від реалізації продукції і темпів росту позикового капіталу, то істотний приріст позикових коштів має бути забезпечений отриманим доходом, що йде на погашення зобов'язань з обслуговування боргу (процентів по кредитах та позиках і т.ін.) і основної суми неоплатних боргів. 
Таблиця 1 - Ранжування темпів зростання показників цільової направленості розвитку промислового підприємства

\begin{tabular}{|l|c|}
\hline \multicolumn{1}{|c|}{ Показник } & Ранг \\
\hline Чистий прибуток & 1 \\
\hline Вартість експортної продукції & 2 \\
\hline Чистий дохід від реалізації продукції & 3 \\
\hline Обсяг виробництва продукції & 4 \\
\hline Оборотні активи & 5 \\
\hline Власний капітал & 6 \\
\hline Інвестиції в основний капітал & 7 \\
\hline Нематеріальні активи & 8 \\
\hline Сукупні активи & 9 \\
\hline Фонд заробітної плати & 10 \\
\hline Середньорічна чисельність персоналу & 11 \\
\hline Собівартість продукції & 12 \\
\hline Кредиторська заборгованість & 13 \\
\hline Дебіторська заборгованість & 14 \\
\hline
\end{tabular}

Крім того, рекомендується оцінити достатність залишків грошових коштів на покриття першочергових платежів (кредиторської заборгованості). Умовою розвитку промислового підприємства $\epsilon$ перевищення темпів зростання обсягу експортованої продукції над темпом зростання виручки, оскільки це є гарантією розширення ринку збуту і підвищення конкурентоспроможності продукції підприємства. Випереджальна динаміка оборотних активів і власного капіталу обумовлює зростання ліквідності і фінансової незалежності, а показника інвестицій в основний капітал над темпами зростання сукупного капіталу підприємства - свідчить про збільшення інтенсивності капітальних вкладень, а отже про нарощування потенціалу розвитку. Щодо співвідношення темпів зростання власного і позикового капіталу, з точки зору кредиторів і інвесторів, власний капітал має зростати швидше, що мінімізує ризики роботи. Фінансовий менеджер підприємства може зробити ставку на переважне зростання позикового капіталу при виборі джерел фінансування бізнесу, але при цьому мають не знижуватися прибутковість позикових коштів та розміри фінансового результату.

Для вибору інноваційного розвитку важливим $\epsilon$ випереджальна динаміка нематеріальних активів над темпом зростання сукупних активів, що указує на інтелектуалізацію капіталу підприємства, а отже забезпечує нарощування потенціалу інноваційного розвитку (Perevozova et al., 2021). Також природно вважати, що валовий прибуток зростає швидше, ніж чисельність працюючих i таким чином зростає продуктивність праці. Тривалість повернення дебіторської заборгованості має знижуватися, що характеризує ефективне управління оборотними активами. Важливою умовою фінансової безпеки підприємства $€$ збалансованість тривалості обороту дебіторської та кредиторської заборгованості. Середній термін погашення дебіторської заборгованості має бути менше терміну погашення кредиторської заборгованості, тобто підприємство спочатку отримує грошові кошти в рахунок погашення зобов'язань від третіх осіб, а потім розплачується за своїми борговими зобов'язаннями, зменшуючи таким чином ризик утворення дефіциту коштів у залишках на рахунках. Дотримання таких умов особливо важливим $\epsilon$ для промислових підприємств, з огляду на нерівномірність виробництва і реалізації готової продукції, а отже і грошових потоків.

Мета статті полягає у розкритті основних положень науково-обґрунтованих 
рекомендацій щодо організації і проведення індивідуальної підготовки офіцерів бригади тактичної авіації, що отримані за допомогою використання удосконаленого науковометодичного апарату.

\section{Виклад основного матеріалу}

\section{Оцінка розвитку підприємства}

Для аналізу скористаємося даними фінансової звітності підприємств ПрАТ «Одесавинпром». Динаміка показників ПрАТ
«Одесавинпром» за період 2009-2015 років на основі даних фінансової звітності підприємств (за даними smida) приведена у таблиці 2.

Таблиця 2 - Показники діяльності ПрАТ «Одесавинпром»

\begin{tabular}{|c|c|c|c|c|c|}
\hline \multirow{2}{*}{ Показник } & \multicolumn{5}{|c|}{ Роки } \\
\hline & 2011 & 2012 & 2013 & 2014 & 2015 \\
\hline Чистий прибуток, тис. грн. & 8061 & -10893 & 2921 & -70435 & -39557 \\
\hline Вартість експортної продукції, дол. США & 515959 & 362532 & 130050 & 48156 & 152333 \\
\hline Чистий дохід від реалізації продукції, тис.грн. & 150478 & 183592 & 180625 & 173148 & 323766 \\
\hline Обсяг виробництва продукції, тис дал & 539 & 414 & 439 & 412 & 477 \\
\hline Оборотні активи, тис. грн. & 164102 & 160652 & 137375 & 122709 & 132538 \\
\hline Власний капітал, тис. грн. & 22567 & 11674 & 13271 & -57164 & -88402 \\
\hline Інвестиції в основний капітал, тис. грн. & 27 & 6548 & 3011 & 85 & 932 \\
\hline Нематеріальні активи, тис. грн. & 295 & 2232 & 1641 & 1107 & 666 \\
\hline Сукупні активи, тис. грн. & 210457 & 208703 & 187937 & 166130 & 173087 \\
\hline Фонд заробітної плати, тис. грн. & 9940 & 10148 & 8679 & 7709 & 9837 \\
\hline Середньорічна чисельність персоналу, чол. & 352 & 317 & 284 & 257 & 291 \\
\hline Собівартість продукції, тис. грн. & 87637 & 111535 & 106373 & 123810 & 263963 \\
\hline Кредиторська заборгованість, тис. грн. & 72500 & 76003 & 68419 & 70366 & 98980 \\
\hline Дебіторська заборгованість, тис. грн. & 111696 & 104452 & 85261 & 64998 & 57154 \\
\hline
\end{tabular}

Наступним етапом $€$ визначення темпів росту значень показників, розрахунок індексів темпів росту, їх ранжування, порівняння ранжованного ряду з еталонним.
Визначимо ланцюгові темпи зростання показників господарської діяльності даного підприємства (табл. 3).

Таблиця 3 - Ланцюгові темпи росту показників господарської діяльності ПрАТ «Одесавинпром»

\begin{tabular}{|l|c|c|c|c|}
\hline \multicolumn{1}{|c|}{ Показник } & \multicolumn{4}{c|}{ Роки } \\
\cline { 2 - 5 } & 2012 & 2013 & 2014 & 2015 \\
\hline Чистий прибуток, тис. грн. & $-1,351$ & $-0,268$ & $-24,113$ & $-0,561$ \\
\hline Вартість експортної продукції, дол. США & 0,703 & 0,359 & 0,370 & 3,163 \\
\hline Чистий дохід від реалізації продукції, тис. грн. & 1,220 & 0,984 & 0,959 & 1,870 \\
\hline Обсяг виробництва продукції, тис дал & 0,768 & 1,060 & 0,938 & 1,158 \\
\hline Оборотні активи, тис. грн. & 0,980 & 0,855 & 0,893 & 1,080 \\
\hline Власний капітал, тис. грн. & 0,517 & 1,137 & $-4,307$ & 1,546 \\
\hline
\end{tabular}




\begin{tabular}{|l|c|c|c|c|}
\hline \multirow{2}{*}{ Показник } & \multicolumn{4}{c|}{ Роки } \\
\cline { 2 - 5 } & 2012 & 2013 & 2014 & 2015 \\
\hline Інвестиції в основний капітал, тис. грн. & 242,519 & 0,460 & 0,028 & 10,965 \\
\hline Нематеріальні активи, тис. грн. & 7,566 & 0,735 & 0,675 & 0,602 \\
\hline Сукупні активи, тис. грн. & 0,992 & 0,901 & 0,884 & 1,042 \\
\hline Фонд заробітної плати, тис. грн. & 1,021 & 0,855 & 0,888 & 1,276 \\
\hline Середньорічна чисельність персоналу, чол. & 0,901 & 0,896 & 0,904 & 1,132 \\
\hline Собівартість продукції, тис. грн. & 1,273 & 0,954 & 1,164 & 2,132 \\
\hline Кредиторська заборгованість, тис. грн. & 1,048 & 0,900 & 1,028 & 1,407 \\
\hline Дебіторська заборгованість, тис. грн. & 0,935 & 0,816 & 0,762 & 0,879 \\
\hline
\end{tabular}

Згідно результатів розрахунків, спостерігається нерівномірна зміна показників, окремі індикатори соціальноекономічного розвитку мають падіння 3 переходом від року до року, інші залишаються незмінними, або зростають в певному часовому інтервалі. Визначення темпів зростання не дозволяє отримати «інтегральну оцінку кінцевої результативності, а оцінює скоріше зміну умов, в яких вона проходила» (Тонких, 2012).

Інтегральну характеристику розвитку підприємства можливо отримати шляхом визначення індексів руху показників, що визначаються через ланцюгові відносини темпів їх зростання, що наочно представляють зміну числової структури оцінок у порівнянні з таблицею 4.

Таблиця 4 - Індекси темпи росту показників господарської діяльності ПрАТ «Одесавинпром»

\begin{tabular}{|l|c|c|c|c|}
\hline \multicolumn{1}{|c|}{ Показник } & \multicolumn{4}{c|}{ Роки } \\
\cline { 2 - 5 } & 2012 & 2013 & 2014 & 2015 \\
\hline Чистий прибуток, тис. грн. & $-1,351$ & 0,198 & 89,973 & 0,023 \\
\hline Вартість експортної продукції, дол. США & 0,703 & 0,511 & 1,031 & 8,549 \\
\hline Чистий дохід від реалізації продукції, тис. грн. & 1,220 & 0,806 & 0,975 & 1,950 \\
\hline Обсяг виробництва продукції, тис дал & 0,768 & 1,380 & 0,885 & 1,235 \\
\hline Оборотні активи, тис. грн. & 0,980 & 0,872 & 1,044 & 1,209 \\
\hline Власний капітал, тис. грн. & 0,517 & 2,199 & $-3,788$ & $-0,359$ \\
\hline Інвестиції в основний капітал, тис. грн. & 242,519 & 0,002 & 0,061 & 391,597 \\
\hline Нематеріальні активи, тис. грн. & 7,566 & 0,097 & 0,918 & 0,892 \\
\hline Сукупні активи, тис. грн. & 0,992 & 0,908 & 0,981 & 1,179 \\
\hline Фонд заробітної плати, тис. грн. & 1,021 & 0,837 & 1,039 & 1,437 \\
\hline Середньорічна чисельність персоналу, чол. & 0,901 & 0,994 & 1,009 & 1,252 \\
\hline Собівартість продукції, тис. грн. & 1,273 & 0,749 & 1,220 & 1,832 \\
\hline Кредиторська заборгованість, тис. грн. & 1,048 & 0,859 & 1,142 & 1,369 \\
\hline Дебіторська заборгованість, тис. грн. & 0,935 & 0,873 & 0,934 & 1,154 \\
\hline
\end{tabular}

Таблиця співвідношень темпів зростання показників відображає оцінку розвитку окремих підсистем підприємства через вибрані показники.

На наступному етапі здійснюється ранжування індексів темпів зростання показників, тобто упорядкування обраних індикаторів.

Рангова оцінка (таблиця 5) дозволяє отримати цілісну порівнянну картину змін, i являє собою числове відображення структурної динаміки, що характеризує розвиток економічної системи в певному часовому інтервалі. 
Таблиця 5 - Рангова оцінка показників розвитку ПрАТ «Одесавинпром»

\begin{tabular}{|l|c|c|c|c|}
\hline \multirow{2}{*}{ Показник } & \multicolumn{4}{c|}{ Роки } \\
\cline { 2 - 5 } & 2012 & 2013 & 2014 & 2015 \\
\hline Чистий прибуток, тис. грн. & 14 & 11 & 1 & 13 \\
\hline Вартість експортної продукції, дол. США & 12 & 12 & 6 & 2 \\
\hline Чистий дохід від реалізації продукції, тис. грн. & 4 & 9 & 9 & 3 \\
\hline Обсяг виробництва продукції, тис дал & 11 & 2 & 12 & 8 \\
\hline Оборотні активи, тис. грн. & 8 & 6 & 4 & 9 \\
\hline Власний капітал, тис. грн. & 13 & 1 & 14 & 14 \\
\hline Інвестиції в основний капітал, тис. грн. & 1 & 14 & 13 & 1 \\
\hline Нематеріальні активи, тис. грн. & 2 & 13 & 11 & 12 \\
\hline Сукупні активи, тис. грн. & 7 & 4 & 8 & 10 \\
\hline Фонд заробітної плати, тис. грн. & 6 & 8 & 5 & 5 \\
\hline Середньорічна чисельність персоналу, чол. & 10 & 3 & 7 & 7 \\
\hline Собівартість продукції, тис. грн. & 3 & 10 & 2 & 4 \\
\hline Кредиторська заборгованість, тис. грн. & 5 & 7 & 3 & 6 \\
\hline Дебіторська заборгованість, тис. грн. & 9 & 5 & 10 & 11 \\
\hline
\end{tabular}

Більшому значенню індексу відповідає найбільший ранг. Найменшому значенню нараховується ранг, що відповідає кількості ранжируваних значень. У разі, якщо кілька значень рівні, проблему співвідношення індексів руху показників можливо вирішити шляхом логічної диференціації рангів, або шляхом зважування отриманих значень.

Можливі два варіанти порівняння рангових упорядкувань, що показують різні властивості і форми зв'язків підсистем підприємства: за відхиленнями і по інверсіям.

У першому випадку визначається відхилення, що відрізняє ранг елемента в аналізованому періоді від його ж рангу в ряду, прийнятому за еталон. Після побудови фактичного рангового ряду показників діяльності підприємства переходимо до порівняння його з еталонним. Порівняння рядів за відхиленнями представлені в таблиці 6.

Таблиця 6 - Порівняння фактичних рангів показників розвитку ПрАТ «Одесавинпром» 3 еталонним рядом за відхиленнями

\begin{tabular}{|c|c|c|c|c|c|}
\hline \multirow[t]{2}{*}{ Показник } & \multirow{2}{*}{$\begin{array}{c}\text { Еталонний } \\
\text { ряд }\end{array}$} & \multicolumn{4}{|c|}{$\begin{array}{c}\text { Відхилення рангів } \\
\text { фактичних від еталонних }\end{array}$} \\
\hline & & 2012 & 2013 & 2014 & 2015 \\
\hline Чистий прибуток, тис. грн. & 1 & 13 & 10 & 0 & 12 \\
\hline Вартість експортної продукції, дол. США & 2 & 10 & 10 & 4 & 0 \\
\hline Чистий дохід від реалізації продукції, тис. грн. & 3 & 1 & 6 & 6 & 0 \\
\hline Обсяг виробництва продукції, тис дал & 4 & 7 & -2 & 8 & 4 \\
\hline Оборотні активи, тис. грн. & 5 & 3 & 1 & -1 & 4 \\
\hline Власний капітал, тис. грн. & 6 & 7 & -5 & 8 & 8 \\
\hline Інвестиції в основний капітал, тис. грн. & 7 & -6 & 7 & 6 & -6 \\
\hline Нематеріальні активи, тис. грн. & 8 & -6 & 5 & 3 & 4 \\
\hline Сукупні активи, тис. грн. & 9 & -2 & -5 & -1 & 1 \\
\hline Фонд заробітної плати, тис. грн. & 10 & -4 & -2 & -5 & -5 \\
\hline Середньорічна чисельність персоналу, чол. & 11 & -1 & -8 & -3 & -4 \\
\hline Собівартість продукції, тис. грн. & 12 & -9 & -2 & -10 & -6 \\
\hline Кредиторська заборгованість, тис. грн. & 13 & -7 & -6 & -10 & -7 \\
\hline Дебіторська заборгованість, тис. грн. & 14 & -5 & -9 & -4 & -3 \\
\hline
\end{tabular}


Недоліком методу порівняння показників за відхиленнями $є$ оцінка кожного елемента системи окремо, без розгляду зв'язків елементів. Для побудови цілісної картини розвитку об'єкта використовується метод порівняння за інверсіями, що враховує перестановки всіх елементів при ранжируванні. Інверсія (порушення нормального порядку елементів в перестановці) показує кількість показників, які порушили порядок рангів щодо показника, за яким здійснюється розрахунок.

Найбільш простий спосіб визначення інверсій полягає в такому: підраховується кількість чисел, що мають менший ранг і розташовані нижче числа розглянутого рангу.

Отримане число $€$ інверсією. У таблиці 7 представлено порівняння фактичного i еталонного рядів методом інверсій.

Таблиця 7 - Порівняння фактичних рангів показників розвитку ПрАТ «Одесавинпром» 3 еталонним рядом по інверсіям

\begin{tabular}{|l|c|c|c|c|c|}
\hline \multicolumn{1}{|c|}{ Показник } & Еталонний & \multicolumn{4}{c|}{ Інверсія } \\
\cline { 3 - 6 } & ряд & 2012 & 2013 & 2014 & 2015 \\
\hline Чистий прибуток, тис. грн. & 1 & 13 & 10 & 0 & 12 \\
\hline Вартість експортної продукції, дол. США & 2 & 10 & 10 & 4 & 0 \\
\hline Чистий дохід від реалізації продукції, тис. грн. & 3 & 1 & 6 & 6 & 0 \\
\hline Обсяг виробництва продукції, тис дал & 4 & 7 & 0 & 8 & 4 \\
\hline Оборотні активи, тис. грн. & 5 & 3 & 1 & 0 & 4 \\
\hline Власний капітал, тис. грн. & 6 & 7 & 0 & 8 & 8 \\
\hline Інвестиції в основний капітал, тис. грн. & 7 & 0 & 7 & 6 & 0 \\
\hline Нематеріальні активи, тис. грн. & 8 & 0 & 5 & 3 & 4 \\
\hline Сукупні активи, тис. грн. & 9 & 0 & 0 & 0 & 1 \\
\hline Фонд заробітної плати, тис. грн. & 10 & 0 & 0 & 0 & 0 \\
\hline Середньорічна чисельність персоналу, чол. & 11 & 0 & 0 & 0 & 0 \\
\hline Собівартість продукції, тис. грн. & 12 & 0 & 0 & 0 & 0 \\
\hline Кредиторська заборгованість, тис. грн. & 13 & 0 & 0 & 0 & 0 \\
\hline Дебіторська заборгованість, тис. грн. & 14 & 0 & 0 & 0 & 0 \\
\hline
\end{tabular}

Для оцінки відмінності фактичних рангів від нормативних використовуються коефіцієнти Спірмена і Кендала.

Коефіцієнт Спірмена враховує відмінності за відхиленнями і визначається за формулою:

$$
p=1-6 \frac{\sum_{i=1}^{n} d_{j}^{2}}{n\left(n^{2}-1\right)} ; 1 \geq p \geq-1 ;
$$

де р - коефіцієнт рангової кореляції Спірмена;

$n$ - число рангів;

$d_{j}^{2}$ - різниця між рангами за факторною ознакою, $Y_{j}$ та

результативного $Y_{j}$, інакше $d_{j}=R_{x j} R_{y j}$.

Коефіцієнт кореляції набуває значень у межах \pm 1 , тобто $1 \geq \rho \geq-1$. Чим ближче $\rho \rightarrow 1$, тим більша узгодженість між результатами тестування. Від'ємне значення $\rho$ свідчить про протилежну узгодженість.

Оскільки різниця в балах може виникнути випадково, необхідно перевірити істотність значення $\rho$ з певним рівнем імовірності $\rho \approx$ 0,95 залежно від кількості рангів $n$. Перевірка здійснюється за відповідною таблицею критичних значень коефіцієнта рангової кореляції Спірмена. Якщо фактичне значення $\rho$ більше критичного $\rho_{0,95}$ $(n)$, тобто $\rho>\rho_{0,95}(n)$, визнається істотним, у протилежному зв'язок випадковий або істотність зв'язку не доведено.

Коефіцієнт кореляції Кендала обчислюється за формулою:

$$
\tau=1-4 \frac{\sum_{i-1}^{n} m_{s}}{n(n-1)}
$$

де $\tau$ - коефіцієнт кореляції Кендала;

$n$ - кількість показників, включених в систему оцінок;

$\mathrm{m}_{\mathrm{s}}$ - сума інверсій

Коефіцієнт кореляції Кендала являється 
інструментом оцінки близькості двох рядів на основі підрахунку інверсій. У цьому методі одна змінна представляється у вигляді монотонної послідовності в порядку зростання величин; іншій змінній привласнюються відповідні рангові місця. Кількість інверсій (порушень монотонності в порівнянні 3 першим рядом) використовується у формулі для кореляційних коефіцієнтів.

Розрахунок коефіцієнтів рангової кореляції дозволяє визначити показник, що інтегрує об'ємну (оцінка за відхиленнями) і структурну (оцінка по інверсіям) сторони діяльності підприємства в єдину оцінку.

Даний коефіцієнт $\in$ інструментом визначення стадії самоорганізації СЕC, виступаючи, таким чином, як інтегральний коефіцієнт самоорганізації CEC (Ксо). За абсолютною величиною даного коефіцієнта кореляції можна робити висновок про ступінь зв'язку між значеннями показників фактичного і еталонного рядів.

Підсумкова оцінка $\mathrm{K}_{\mathrm{co}}$, отримана на підставі двох коефіцієнтів кореляції (коефіцієнтів Спірмена і Кендала) визначаться за формулою:

$$
\mathrm{K}_{\mathrm{co}}=\frac{(1+\mathrm{p})(1+\mathcal{T})}{4},
$$

де $K_{c o}{ }^{-}$коефіцієнт самоорганізації підприємства.

Отримані значення коефіцієнтів Спірмена, Кендала і самоорганізації підприємства представлені в таблиці 8.

Таблиця 8 - Коефіцієнти самоорганізації розвитку ПрАТ «Одесавинпром»

\begin{tabular}{|l|c|c|c|c|}
\hline \multicolumn{1}{|c|}{ Показник } & \multicolumn{4}{c|}{ Роки } \\
\cline { 2 - 5 } & 2014 & 2015 & 2016 & 2017 \\
\hline Коефіцієнт рангової кореляції Спірмена $(p)$ & 0,8571 & $-0,2176$ & $-0,0484$ & 0,0593 \\
\hline Коефіцієнт кореляції Кендалла $(\tau)$ & 0,1648 & 0,1429 & 0,2308 & 0,2747 \\
\hline Коефіцієнт самоорганізації підприємства $\left(K_{c o}\right)$ & 0,1720 & 0,2236 & 0,3266 & 0,4574 \\
\hline
\end{tabular}

3 використанням таблиці критичних значень коефіцієнтів рангової кореляції Спірмена визначаємо критичне значення (p) для заданого кількості елементів (у даному випадку, $\mathrm{n}=14)$. У даному прикладі для $\mathrm{n}=14$ критичне значення становить 0,68. Якщо розрахункове значення (p) перевищує критичне або, принаймні, дорівнює йому, фактичний ранжирований ряд близький до еталонного. Розрахунки показали значну різницю наявного стану розвитку досліджуваного підприємства від еталонного. Від`ємне значення коефіцієнта рангової кореляції Спірмена (р) свідчить про протилежну узгодженість показників, тобто про наявність кризи на підприємстві.

Коефіцієнти Кендалла і Спірмена дають оцінку близькості одного рангового ряду до іншого, еталонного, на інтервалі від +1 до -1. Результат рівний (+1) виходить, якщо ранги пари обох рядів розташовані в однаковій послідовності (тобто при збігу порівнюваного порядку 3 еталонним). Негативне значення свідчить про повну різнонаправленість напрямків руху показників еталонного i фактичного рядів.

Отримані негативні значення коефіцієнтів Спірмена i Кендалла для досліджуваного підприємства свідчать про розвиток підприємства, який істотно відрізняється від бажаного (запланованого) сценарію.

Оцінка Ксо змінюється в діапазоні від 0 до 1. Значення коефіцієнта, рівне 1 , свідчить про збіг фактичного і заданого в еталонній системі порядку показників, коли усі нормативно установлені співвідношення темпів зростання показників фактично виконуються. Таке співвідношення характерне для найбільш ефективного рівня реалізації фінансової, кадрової, маркетингової, інвестиційної політики підприємства. Чим ближче значення $\mathrm{K}_{\text {со до }} 1$, тим більше еталонних темпів зростання показників дотримується. Значення, рівне 0, вказує про неефективність господарської діяльності підприємства, коли фактичне співвідношення індексів руху 
показників суперечить установленому інтерпретацій коефіцієнтів кореляції можна еталонному.

На основі прийнятих в статистиці чисельних оцінити близькість розвитку двох режимів діяльності: фактичного і еталонного.

Таблиця 9 - Шкала значень коефіцієнта самоорганізації розвитку підприємств з позиції варіантів управлінського впливу

\begin{tabular}{|c|c|c|c|c|}
\hline $\begin{array}{c}\text { Інтервали } \\
\text { значень } \\
\text { коефіцієнта } \\
\text { самоорганізації } \\
\text { розвитку } \\
\end{array}$ & $\begin{array}{c}\text { Ступінь зв язку } \\
\text { між еталонним і } \\
\text { фактичним } \\
\text { співвідношенням } \\
\text { показників } \\
\end{array}$ & $\begin{array}{c}\text { Стадія } \\
\text { самоорганізації }\end{array}$ & $\begin{array}{c}\text { Зона } \\
\text { розвитку }\end{array}$ & $\begin{array}{c}\text { Вибір варіантів управлінського } \\
\text { впливу }\end{array}$ \\
\hline$[0,0-0,2)$ & Відсутній & $\begin{array}{l}\text { Побудова } \\
\text { нової моделі } \\
\text { самоорганізації } \\
\text { підсистем } \\
\end{array}$ & Біфуркації & $\begin{array}{l}\text { Цілеспрямована } \\
\text { самоорганізація, будування } \\
\text { нової системи, здатної до } \\
\text { самоорганізації }\end{array}$ \\
\hline$[0,2-0,4)$ & Слабкий & $\begin{array}{l}\text { Перехідна } \\
\text { стадія }\end{array}$ & Критична & $\begin{array}{l}\text { Цілеспрямована } \\
\text { самоорганізація, без опори на } \\
\text { самоорганізацію підсистем }\end{array}$ \\
\hline$[0,4-0,7)$ & $\begin{array}{l}\text { Середній } \\
\text { (помірний) }\end{array}$ & $\begin{array}{l}\text { Динамічна } \\
\text { рівновага }\end{array}$ & Нормальна & $\begin{array}{l}\text { Самоорганізація і } \\
\text { цілеспрямований вплив } \\
\text { співвідносяться у рівному } \\
\text { ступені }\end{array}$ \\
\hline$[0,7-1,0]$ & Сильний & $\begin{array}{l}\text { Динамічна } \\
\text { рівновага }\end{array}$ & Еталонна & $\begin{array}{l}\text { Перевага процесів } \\
\text { самоорганізації підсистем, при } \\
\text { необхідності - їх регулювання, } \\
\text { направлене на повернення } \\
\text { системи до стану рівноваги }\end{array}$ \\
\hline
\end{tabular}

Співвідношення процесів самоорганізації і управлінських впливів залежить від значення Ксо таким чином: зі збільшенням коефіцієнта кореляції зростає рівень самоорганізації підсистем підприємства.

Кожній стадії процесу самоорганізації відповідає певне значення коефіцієнта Ксо. Таким чином, підприємство в циклі саморозвитку може перебувати в таких зонах: біфуркація, критична зона, нормативна та еталонна.

Траєкторія розвитку «Одесавинпром» за 2014-2017 рр., побудована на основі розрахованих коефіцієнтів самоорганізації, представлена на рисунку 2.

У таблиці 9 представлена ступінь тісноти зв'язку між фактичним i еталонним співвідношенням показників і відповідні варіанти вибору управлінських впливів в залежності від значення коефіцієнта самоорганізації.

В цілому, представлений графік свідчить про знаходження підприємства в критичній зоні, з високим рівнем біфуркації. Згідно даних таблиці 8, при такій стадії самоорганізації переважають цілеспрямовані управлінські впливи, а самоорганізація внутрішніх підсистем зведена до мінімуму. Починаючи з 2015 року, підприємство потрапило В зону біфуркації, яка характеризується переглядом і глибоким переосмисленням стратегії, постановкою нових цілей, формування якісно нової структури самоорганізації. 


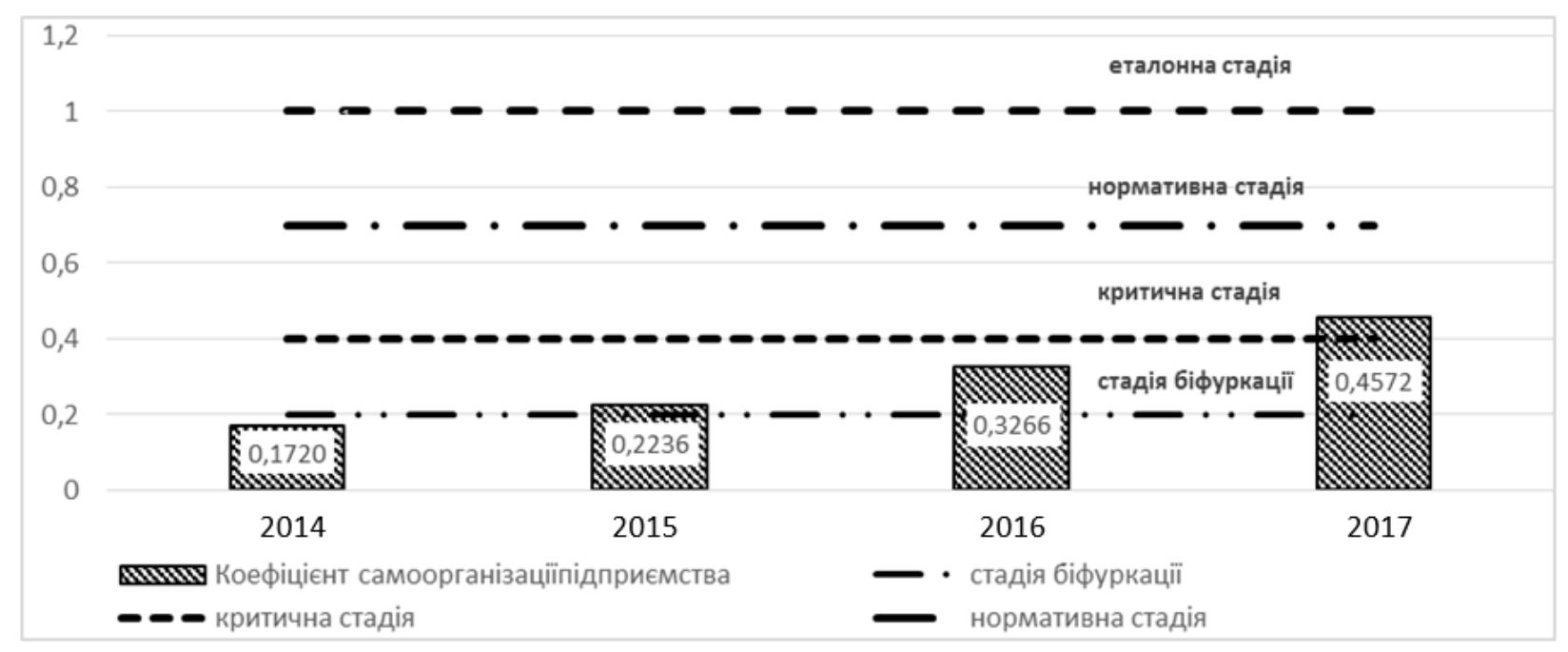

Рисунок 2 - Співвідношення коефіцієнта самоорганізації підприємства із стадіями його розвитку

Для переходу підприємства в стадію динамічної рівноваги необхідно розробити комплекс оптимального управлінського впливу, що сприятиме реалізації потенціалу самоорганізації підприємства і досягненню траєкторії розвитку, максимально наближеної до ідеалу.

Таким чином, розглянутий метод динамічних нормативів в діагностиці розвитку підприємства має низку переваг:

- заснований на оцінці результативності системи у вигляді приросту показників (враховується властивість динамічності, як основної характеристики самоорганізації CEC, а також нерівномірний рух різних показників у досліджуваному часовому інтервалі);

- дозволяє привести показники різної розмірності у співставну числову характеристику;

- невелика кількість показників дає змогу побачити спектр "реальних динамічних станів" в суб'єкті оцінки;

- дозволяє проаналізувати внутрішню будову будь-якого об'єкта і співвідношення його окремих частин;

- відображає сукупність різнорідних властивостей усіх взаємозалежних елементів, підкреслюючи унікальність участі кожного елемента в формуванні загального результату;

- придатний для оцінки розвитку СЕС макро-, мезо- і мікрорівня.
Запропонований інструментарій для вибору управлінського впливу на економічну систему, який заснований на методах динамічних нормативів, $€$ при цьому елементом цілісного механізму управління самоорганізацією CEC.

Рівень самоорганізації СЕС дає можливість оцінити адаптивний потенціал підприємства. Адаптацію, в широкому значенні, розуміють як пристосування системи до зміни умов. Адаптивний потенціал - здатність СЕС адаптуватися до змін. Пропонується визначати адаптивний потенціал промислового підприємства як різницю запасу можливостей системи самоорганізації підприємства за досліджуваний період i локально досягнутого рівня самоорганізації від одиниці (відстань до еталонної стадії):

$$
\left\{\begin{array}{l}
3 \mathrm{M}_{\mathrm{c}}=1-\sum_{i=1}^{n} \mathrm{~K}_{\mathrm{Co}_{i}} \frac{1-\overline{\mathrm{K}_{\mathrm{CO}_{l}}}}{n} \\
\Pi_{\text {ддапт }}=1-\left(3 \mathrm{M}_{\mathrm{co}}-\mathrm{K}_{\mathrm{CO}_{i}}\right)
\end{array}\right.
$$

де $\Pi_{\text {адапт }}-$ адаптивний потенціал підприємства; $3 \mathrm{M}_{\mathrm{c}}-$ запас можливостей системи самоорганізації підприємства; $\frac{1-\overline{\mathrm{K}_{\mathrm{CO}_{l}}}}{n}$ - швидкість розвитку підприємства; $\overline{\mathrm{K}_{\mathrm{CO}_{l}}}-$ середнє арифметичне коефіцієнта самоорганізації; $i$ - досліджуваний період, $n-$ кількість років. 
Дослідження проводилось за період 5 потенціалу років. Отримані значення адаптивного таблиці 10.

\section{років. Отримані значення адаптивного таблиці 10.}

Таблиця 10 - Адаптивний потенціал ПрАТ «Одесавинпром»

\begin{tabular}{|l|c|c|c|c|}
\hline \multicolumn{1}{|c|}{ Показник } & \multicolumn{3}{|c|}{ Роки } \\
\cline { 2 - 5 } & 2014 & 2015 & 2016 & 2017 \\
\hline Адаптивний потенціал, $\left(\Pi_{\text {адапт }}\right)$ & 0,3383 & 0,3899 & 0,4929 & 0,6237 \\
\hline Коефіцієнт самоорганізації підприємства, $\left(K_{\text {со }}\right)$ & 0,1720 & 0,2236 & 0,3266 & 0,4574 \\
\hline $\begin{array}{l}\text { Запас моментної економічної стійкості } \\
\text { підприємства, }\left(3 \mathrm{M}_{\mathrm{c}}\right)\end{array}$ & & \multicolumn{3}{|c|}{0,8337} \\
\hline
\end{tabular}

При цьому, розрахована величина адаптивного потенціалу на основі показника самоорганізації, $€$ динамічним показником, який може виступати як критерій оцінки результативності управлінської системи підприємства. За даними розрахунків адаптивного потенціалу, ПрАТ «Одесавинпром» не використовує свої можливості самоорганізації на 83,37\%. Проте, адаптивний потенціал має позитивне значення, реалізується у 2012 році на 33,83\%, у 2013 році на 38,99\%, у 2014 році на 49,29\%, у 2015 році на 62,37\%. Це говорить про те, що реалізація адаптивного потенціалу підприємства наростає, рівень самоорганізації CEC підвищується, хоча підприємство і знаходиться у зоні кризи, проте, є надія на те, що сформована система управління спроможна вивести підприємство в стадію динамічної рівноваги.

Основною умовою ефективного функціонування і розвитку промислових підприємств є забезпечення належного рівня стійкості.

Розуміючи під стійкістю підприємства, як системи, здатність зберігати себе, існувати і динамічно розвиватися, важливо виділити параметри при наявності збурень, які порушують нормальний хід бізнес-процесів. Такі параметри не є стабільними величинами, знаходяться в певній, мінливій в часі, зоні.

Серед процесів, в результаті яких створюється додана вартість, найвищого порядку набувають процеси активної адаптації.

Адаптивне управління - $є$ окремим видом управління, а саме, гнучким, інноваційним управлінням підприємствами, здатними пристосуватися до нових умов середовища за допомогою нових інструментів і методів управління.

Якостями адаптивного характеру для промислового підприємства, виділяються наступні: наявність системи управління змінами - для визначення цільових векторів розвитку, спираючись на підходи випереджаючого розвитку; організація інноваційної діяльності; мотивація і розвиток персоналу, управління знаннями; формування інноваційної культури; управління інноваційними ризиками; організація фінансування інноваційної діяльності.

Механізм адаптивного управління підприємством є за своєю сутністю, технологіє виведення підприємства в стадію динамічної рівноваги, згідно таких підходів:

- комплексний підхід (враховуються всі управлінські аспекти і їх взаємозв'язок);

- інтегральний підхід (досліджуються всі процеси (по вертикалі і по горизонталі));

- динамічний, відтворювальний i iнші підходи, що надає системі більшу гнучкість і розширює можливості до диверсифікації.

Система адаптивного управління має стимулювати створення умов для адекватної реакції на зміни зовнішнього і внутрішнього середовища, створювати додаткові можливості розширення спектру відбору варіантів поведінки в конкретних ситуаціях. Це дозволить розробляти і приймати ефективні управлінські рішення, формувати стратегічні 
орієнтири і цілі, розробляти інноваційні програми, реалізовувати інвестиційні проекти.

Одним із елементів системи адаптивного управління має стати механізм управління, що враховує мотивацію інноваційної діяльності.

Під адаптивним механізмом стійкого розвитку підприємства як складної СЕС розуміється сукупність цілей, методів, послідовність цілеспрямованих дій 3 виявлення, оцінки та мінімізації негативного впливу зовнішніх і внутрішніх факторів, які впливають на систему, в результаті чого виникає здатність і додаткові умови переходу системи із стану динамічної рівноваги до стійкого розвитку. Механізм адаптивного управління розвитком підприємства $\epsilon$ частиною загальної системи управління, що забезпечує вплив на чинники, від стану яких залежить результат діяльності керованого об'єкта. Це можливо на основі реалізації процесу адаптивного управління (рисунок 3).

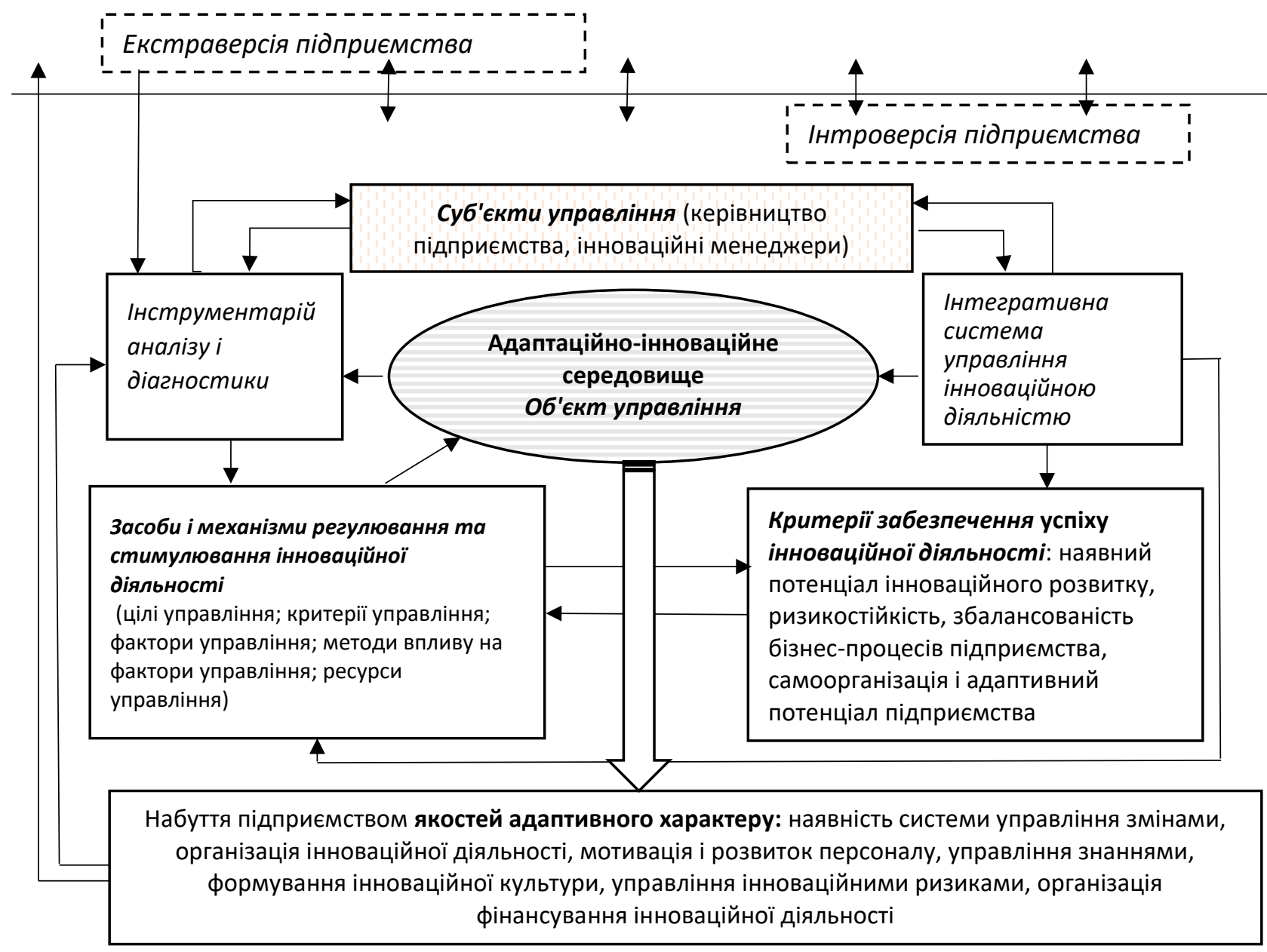

Рисунок 3 - Механізм адаптивного управління розвитком підприємства на основі формування адаптаційно-інноваційного середовища

Результат адаптивного спрямований стабільності, привабливості, стимулювання інноваційної активності, що сприятиме підвищенню конкурентоспроможності, стимулюванню інвестиційно-інноваційного позитивним змінам індикаторів стійкого розвитку підприємства. Забезпечення стійкості інноваційного розвитку підприємства залежить від гнучкості системи адаптивного управління до реформування наявних внутрішніх і зовнішніх факторів i створення компетенцій в майбутньому. 


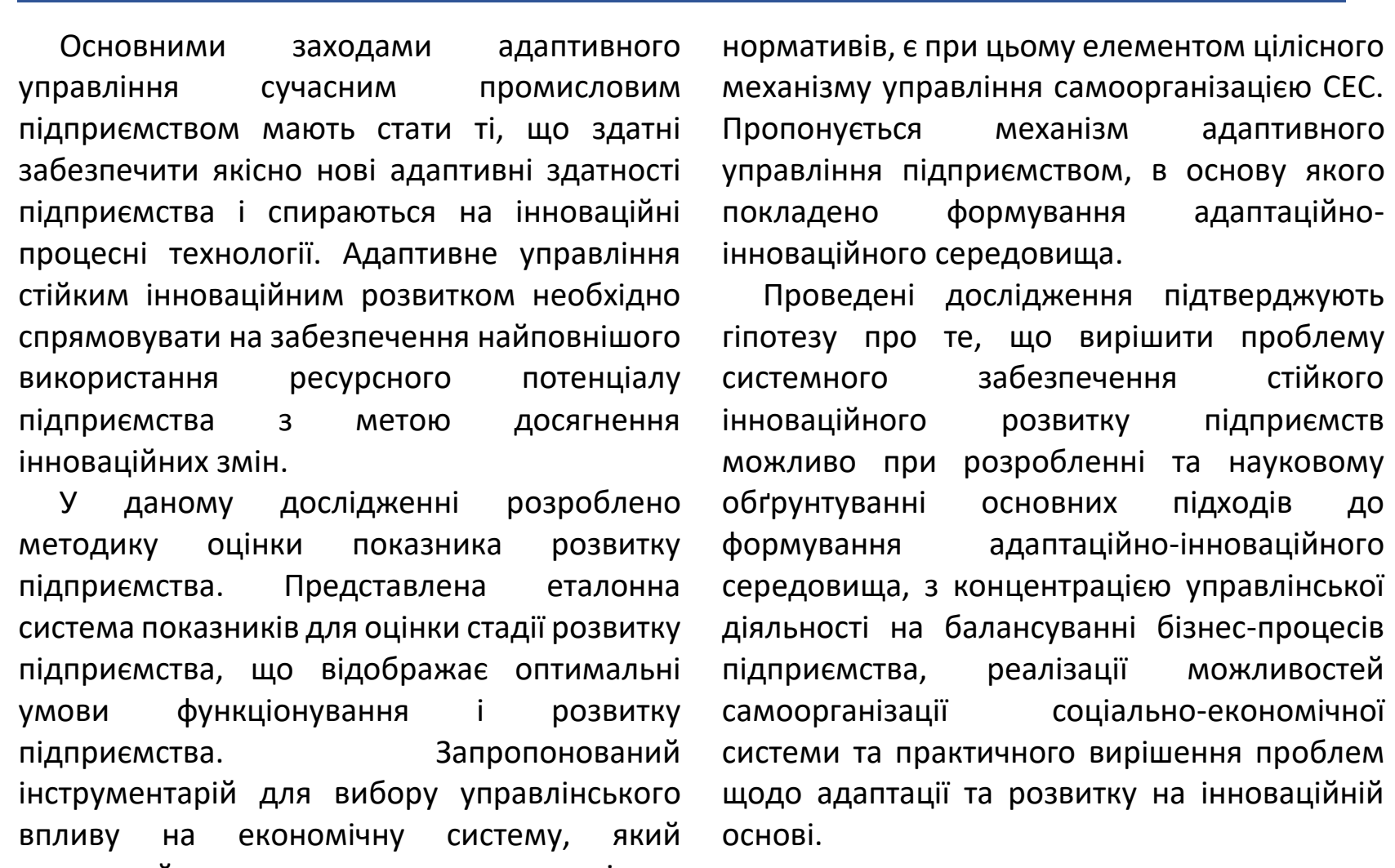
оснований на методах динамічних

\section{Список використаних джерел}

1. Hellwig Z. (1968). Zastosowanie metody taksonomicznej do tupologicznego podzialu krajow ze wzgledu na poziom ich rozwoju $i$ strukture wyktalifikowanych kadr. Pzeglad Statistyczny, №4, 307-326.

2. Perevozova, I., Dzoba, O., Minakova, S., Bondarenko, S., \& Vasylyk, O. (2021). Current asset management of industrial enterprises in the context of implementation of a marketing strategy. Journal of Scientific Papers "Social Development and Security», 11(1), 237-258. DOI: $10.33445 / s d s .2021 .11 .1 .21$

3. Бондаренко С. А. (2017). Стійкий інноваційний розвиток промислового підприємства: антикризові механізми забезпечення : монографія. Харків: вид-во «ПромАрт», 607 с.

4. Бондаренко С. А. (2018). Системне забезпечення стійкого інноваційного розвитку виноробних підприємств : монографія. НАН України, ІН-т пробл. ринку та екон.-екол. дослідж. Одеса: ІПРЕЕД НАНУ, $563 \mathrm{c.}$

5. Гаркуша О.Ю., Смирнов Є.М.(2014).
Комплексна оцінка збалансованості розвитку виноробних підприємств : науково-методичний аспект / Економічний нобелівський вісник, № 1 (7), С. 95-103.

6. Ефимова О. В. (2002). Финансовый анализ. М. : Экономика, $528 \mathrm{c.}$

7. Кондратьев Н. Д. (1989). Проблемы экономической динамики. М.: Экономика, $526 \mathrm{c}$.

8. Мажажихов, А. А. Мисходжев Э. Р. (2012). Динамические нормативные модели диагностики экономической устойчивости промышленного предприятия. Вестник Санкт-Петербургского университета Государственной противопожарной службы МЧС России, № 2. С. 89-96.

9. Макаров А. А. (2011). Использование метода динамического норматива для оценки эффективности функционирования теплоснабжающих предприятий. Вестник УрФУ, № 1, С. 38-43.

10. Михайлов А. В. (2009). Анализ финансовохозяйственной системы субъекта на основе интегральных оценок (метод 
динамического норматива). Известия СанктПетербургского университета экономики и финансов, № 3, С. 177-180.

11. Плюта В., Иванова В. (1989). Сравнительный многомерный анализ в эконометрическом моделировании. М.: Финансы и Статистика, $174 \mathrm{c}$.

12. Погостинская Н. Н., Погостинский Ю. А., Жамбекова Р. Л., Ацканов Р. Р. (2000). Экономическая диагностика: теория и методы. Нальчик : Эльбрус, 320 с.

13. Сыроежин, И. М. (1980). Совершенствование системы показателей эффективности и качества. М.: Экономика, 192 c.

14. Тищенко А. Н., Кизим Н. А., Догайдайло Я. В.
(2005). Экономическая результативность деятельности предприятия: монография / X. : ИНЖЭК, $144 \mathrm{c}$.

15. Тонких А.С., Остальцев А.С., Остальцев И.С. (2012). Моделирование экономического роста предприятия: предпосылки разработки альтернативных моделей. Управление экономическими системами. №9 (45). URL: http://uecs.ru/index.php?option=com_flexico ntent \&view=items\&id=1566.

16. Фольмут Х. Й. (2001). Инструменты контроллинга от А до Я: Пер. с нем. / Под ред. М. Л. Лукашевича и Е. Н. Тихоненковой. М. : Финансы и статистика, 288 с.

\title{
Адаптивное управление в самоорганизации промышленного предприятия
}

\author{
Светлана Бондаренко ${ }^{1 \text { A }}$; Елена Маковеева ${ }^{2 \text { B }}$ \\ ${ }^{1}$ Corresponding author: д.э.н., профессор кафедры оборонного менеджмента, e-mail: lana.bond@ukr.net, ORCID: 0000-0002-1687-1172 \\ 2 к.э.н., доцент, доцент кафедры менеджмента организаций, e-mail: makoveeva.e@ukr.net, ORCID: 0000-0003-2726-915X \\ А Национальный университет обороны Украины имени Ивана Черняховского, пр-кт Воздухофлотский, 28, г. Киев, 03049, Украина \\ в Одесский региональный институт государственного управления Национальной академии государственного управления при Президенте \\ Украины, ул. Генуэзская, 22, Одесса, 65009, Украина
}

\begin{abstract}
Аннотация
В статте проведено исследование адаптивного управления в контексте обеспечения надлежащего уровня самоорганизации промышленного предприятия. В статье доказано, что решить проблему системного обеспечения устойчивого инновационного развития предприятий возможно при разработке и научном обосновании основных подходов к формированию адаптационно-инновационной среды, с концентрацией управленческой деятельности на балансировании бизнес-процессов предприятия, реализации возможностей самоорганизации социально-экономической системы и практического решения проблем адаптации и развития на основе инноваций. В статье представлена методика оценки показателя развития предприятия, что позволяет определить интегральный коэффициент его самоорганизации. Разработана модель для оценки адаптивного потенциала предприятия с использованием показателя скорости развития предприятия. При этом, рассчитанная величина адаптивного потенциала на основе показателя самоорганизации, является динамичным показателем, который может выступать в качестве критерия оценки эффективного управленческой системы предприятия. Разработана шкала значений коэффициента самоорганизации развития предприятий с позиции вариантов управленческого воздействия. Предложенный инструментарий для выбора управленческого воздействия на экономическую систему, основанный на методах динамических нормативов. Предлагается механизм адаптивного управления предприятием, в основе которого формирование адаптационноинновационной среды. Качествами адаптивного характера для промышленного предприятия выделяются следующие: наличие системы управления изменениями; организация инновационной деятельности; мотивация и развитие персонала, управление знаниями; формирование инновационной культуры; управления инновационными
\end{abstract}


рисками; организация финансирования инновационной деятельности.

Ключевые слова: адаптивное управление, адаптивный потенциал, самоорганизация, промышленное предприятие.

\title{
Adaptive management in self-organization of industrial enterprise
}

\author{
Svitlana Bondarenko * 1A; Olena Makoveieva ${ }^{2 \mathrm{~B}}$ \\ * Corresponding author: ${ }^{1}$ Dr of Economics, Professor of the Department, e-mail: lana.bond@ukr.net, ORCID: 0000-0002-1687-1172 \\ ${ }^{2}$ candidate of economics science, associate professor, associate professor of the Department, e-mail: makoveeva.e@ukr.net, ORCID: 0000-0003-2726-915X \\ A National Defence University of Ukraine named after Ivan Cherniachovskyi, 28, Povitroflotsky, ave, Kyiv, 03049, Ukraine \\ ${ }^{B}$ Odessa Regional Institute of Public Administration of the National Academy of Public Administration under the President of Ukraine, Genoezskaya \\ Street, 22, Odessa, 65009, Ukraine
}

\begin{abstract}
The aim of the article is to study adaptive management in the context of ensuring the appropriate level of self-organization of an industrial enterprise. The relevance of the study is due to the need to develop a mechanism of adaptive management of the enterprise as an open socio-economic system capable of self-organization, which allows you to organically combine the properties of stability and, at the same time, flexibility and adaptability. The article presents a method for assessing the development of the enterprise. There is also a reference system of indicators for assessing the stage of development of the enterprise, which reflects the optimal conditions for its operation and development. Spearman and Kendall coefficients are used to assess the difference between actual and normative ranks. The calculation of rank correlation coefficients allows to determine the indicator that integrates the volume and structural scope of the enterprise in a single assessment. The proposed coefficient is a tool for determining the stage of self-organization of the socio-economic system, thus acting as an integral coefficient of self-organization. From the absolute value of this correlation coefficient, we can conclude about the degree of relationship between the values of the actual and reference series. The scale of values of coefficient of self-organization of development of the enterprises from a position of variants of administrative influence is developed. The proposed tools for the choice of managerial influence on the economic system, which is based on the methods of dynamic standards, is an element of a holistic mechanism for managing the self-organization of the socioeconomic system. The level of self-organization makes it possible to assess the adaptive potential of the enterprise as the ability to adapt to change. The model for an estimation of adaptive potential of the enterprise with use of an indicator of speed of development of the enterprise is offered. At the same time, the calculated value of adaptive potential based on the indicator of self-organization is a dynamic indicator that can act as a criterion for assessing the effective management system of the enterprise. The mechanism of adaptive management of the enterprise which basis is based on formation of the adaptive-innovative environment is offered. Adaptation-innovation environment is considered as a set of mutually agreed conditions of internal and external environment of the enterprise, which are outlined by the mechanisms of market, state regulation and stimulation of creation and implementation of innovations, as well as tools and methods that promote innovative development. social qualities of adaptive nature in the implementation of changes in financial and economic activities in response to the variability of the socio-economic environment. The conducted research confirms the hypothesis that it is possible to solve the problem of system support of sustainable innovative development of enterprises by developing and scientifically substantiating the main approaches to the formation of adaptive-innovative environment, with concentration of managerial activity on balancing business processes of the enterprise. problems of adaptation and development on an innovative basis.
\end{abstract}

Keywords: adaptive management, adaptive potential, self-organization, industrial enterprise. 
1. Hellwig Z. (1968). Zastosowanie metody taksonomicznej do tupologicznego podzialu krajow ze wzgledu na poziom ich rozwoju i strukture wyktalifikowanych kadr. Pzeglad Statistyczny, №4, 307-326.

2. Perevozova, I., Dzoba, O., Minakova, S., Bondarenko, S., \& Vasylyk, O. (2021). Current asset management of industrial enterprises in the context of implementation of a marketing strategy. Journal of Scientific Papers "Social Development and Security», 11(1), 237-258. DOI: 10.33445/sds.2021.11.1.21

3. Bondarenko S. A. (2017). Stiikyi innovatsiinyi rozvytok promyslovoho pidpryiemstva: antykryzovi mekhanizmy zabezpechennia : monohrafiia. Kharkiv: vyd-vo «PromArt», 607 $\mathrm{s}$.

4. Bondarenko S. A. (2018). Systemne zabezpechennia stiikoho innovatsiinoho rozvytku vynorobnykh pidpryiemstv : monohrafiia. NAN Ukrainy, In-t probl. rynku ta ekon.-ekol. doslidzh. Odesa: IPREED NANU, $563 \mathrm{~s}$.

5. Harkusha O. Yu., Smyrnov Ye. M. (2014). Kompleksna otsinka zbalansovanosti rozvytku vynorobnykh pidpryiemstv : naukovo-metodychnyi aspekt / Ekonomichnyi nobelivskyi visnyk, № 1 (7), S. 95-103.

6. Efymova O. V. (2002). Fynansovbi analyz. Moscow: Ekonomyka, $528 \mathrm{~s}$.

7. Kondratev N. D. (1989). Problemb ekonomycheskoi dynamyky. Moscow: Ekonomyka, $526 \mathrm{~s}$.

8. Mazhazhykhov, A. A. Myskhodzhev Э. R. (2012). Dynamycheskye normatyvnue modely dyahnostyky эkonomycheskoi ustoichyvosty prombshlennoho predpryiatyia. Vestnyk SanktPeterburhskoho unyversyteta
Hosudarstvennoi protyvopozharnoi sluzhbы MChS Rossyy, № 2. S. 89-96.

9. Makarov A. A. (2011). Yspolzovanye metoda dynamycheskoho normatyva dlia otsenky эffektyvnosty funktsyonyrovanyia teplosnabzhaiushchykh predpryiatyi. Vestnyk UrFU, № 1, S. 38-43.

10. Mykhailov A. V. (2009). Analyz fynansovokhoziaistvennoi systemb subъekta na osnove yntehralnokh otsenok (metod dynamycheskoho normatyva). Yzvestyia Sankt-Peterburhskoho unyversyteta эkonomyky y fynansov, № 3, S. 177-180.

11. Pliuta V., Yvanova V. (1989). Sravnytelnыi mnohomernui analyz $v$ эkonometrycheskom modelyrovanyy. Moscow: Fynansb y Statystyka, $174 \mathrm{~s}$.

12. Pohostynskaia N. N., Pohostynskyi Yu. A., Zhambekova R. L., Atskanov R. R. (2000). Эkonomycheskaia dyahnostyka: teoryia $\mathrm{y}$ metodb. Nalchyk : Эlbrus, $320 \mathrm{~s}$.

13. Siroezhyn, Y. M. (1980). Sovershenstvovanye systemb pokazatelei эffektyvnosty y kachestva. M.: Эkonomyka, $192 \mathrm{~s}$.

14. Tyshchenko A. N., Kyzym N. A., Dohaidailo Ya. V. (2005). Ekonomycheskaia rezultatyvnost deiatelnosty predpryiatyia: monohrafyia / Kh. : YNZhЭK, $144 \mathrm{~s}$.

15. Tonkykh A.S., Ostaltsev A.S., Ostaltsev Y.S. (2012). Modelyrovanye эkonomycheskoho rosta predpryiatyia: predposыlky razrabotky alternatyvnыkh modelei. Upravlenye эkonomycheskymy systemamy. №9 (45). Available from: http://uecs.ru/index.php?option=com_flexic ontent \&view=items\&id=1566.

16. Folmut Kh. Y. (2001). Ynstrumentb kontrollynha ot A do Ya: Per. s nem. / Pod red. M. L. Lukashevycha y E. N. Tykhonenkovoi. Moscow: Fynansы y statystyka, 288 s. 